\title{
Improvement interventions: To what extent are they manifestations of social defences?
}

\author{
Author: \\ Jeremias J. de Klerk ${ }^{1,2}$ \\ Affiliations: \\ ${ }^{1}$ School of Management, \\ University of the Free State, \\ South Africa \\ ${ }^{2}$ Sasol, South Africa \\ Correspondence to: \\ Mias de Klerk \\ Email: \\ mias.deklerk@sasol.com \\ Postal address: \\ Suite 174, Private Bag X17, \\ Weltevredenpark 1715 , \\ South Africa \\ Dates: \\ Received: 28 June 2011 \\ Accepted: 20 Oct. 2011 \\ Published: 13 Feb. 2012 \\ How to cite this article: \\ De Klerk, J.J. (2012). \\ Improvement interventions: \\ To what extent are they \\ manifestations of social \\ defences? SA Journal of \\ Industrial Psycholgy/SA \\ Tydskrif vir Bedryfsielkunde, \\ 38(2), Art. \#999, 10 pages. \\ http://dx.doi.org/10.4102/ \\ sajip.v38i2.999
}

(C) 2012. The Authors.

Licensee: AOSIS

OpenJournals. This work

is licensed under the

Creative Commons

Attribution License.
Orientation: The statistical record of change and improvement interventions to deliver on expectations is notoriously poor. Yet, new interventions are started constantly.

Research purpose: The aim is to provide an explanation to the lure behind interventions and to contribute to building a theory on plausible systems psychodynamic drivers and mechanisms of recurrent change interventions.

Motivation for the study: This study provides insights into social defences in ways that did not receive much attention previously; specifically how defence mechanisms act as drivers for new change and improvement interventions.

Research design, approach and method: A literature study, consisting of a literature review and a phenomenological analysis. The study was conducted from the systems psychodynamic approach.

Main findings: Improvement interventions often represent defences that serve to contain anxieties or maintain fantasies. Four specific themes emerged: interventions defend the perception of being in control, they maintain the fantasy that one is busy with worthy actions to overcome challenges, they are defences against boredom or contain anxieties about incompetence, and they maintain the fantasy of being heroic leaders.

Practical/managerial implications: The findings can assist leaders to understand their own defences in order to avoid embarking on non-essential interventions. This can free up much time, energy and effort to spend on other priorities, assisting organisations to achieve better results.

Contribution/value-add: The study refutes the notion that improvement interventions are always rational coping mechanisms and highlights the role of improvement interventions as defences to reduce anxiety, even though they may contribute little to organisational survival in real terms.

\section{Introduction}

There seems to be a disease going around in many organisations. The symptoms which present themselves, are a stream of continual change and improvement interventions, with one initiative scarcely absorbed before the next is forced upon the organisation (Sorge \& Van Witteloostuijn, 2004). The rational argument for interventions is that without change, the competitive pressures that confront organisations will lead to their downfall (Vinger \& Cilliers, 2006). On the other hand, change and improvement interventions are notoriously ineffective in delivering on expectations (Griffith, 2002). So, what is the lure for leaders to continue initiating more interventions so eagerly? Clearly, something irrational is happening that warrants investigation and explanation.

\section{Background}

We live and work in a competitive environment. Compared to earlier times, work exerts more timerelated demands than ever (Welsh, 2005). Even with a working day that virtually spans twentyfour hours, seven days a week through the availability of modern electronic communication technology, time has become the scarcest resource in many organisations (Davenport \& Prusak, 2000). Managers must now make decisions in a fraction of the time previously devoted to similar decisions. The pressure to act and to act quickly becomes an escalating organisational problem as the need increases to make non-programmed decisions in a global environment that is everchanging (Harvey, Novicevic, Buckley \& Halbesleben, 2004).

In this volatile organisational context, maintaining the status quo is often equated to business suicide (e.g., Kotter \& Schlesinger, 2008; Linklater \& Kellner, 2008). The mantra 'change is the only constant' became clichéd, notwithstanding any potential truth in it. To cope with an 
increasingly hostile environment, organisations have turned to a growing number of improvement interventions, such as changes in strategy, structure, policies, procedures, processes and culture, Total Quality Management (TQM), re-engineering, centralisation and decentralisation, benchmarking, downsizing, and many more (Cordery, 2004; Krantz, 2010; Perkmann \& Spicer, 2008; Siegal et al., 1996). Implementing interventions became universally accepted as a business imperative - it is often not the case of whether the organisation will embark on them, but rather when. Many interventions are successful; many more are costly failures, only to be followed by yet another intervention (Sorge \& Van Witteloostuijn, 2004).

\section{Is the plethora of interventions justified?}

There appears to be a collective belief that interventions will lead to success (Perkmann \& Spicer, 2008). However, research data across different types of interventions, consistently shows that they rarely deliver on anticipated goals. Studies of more than 500 interventions indicate failure rates between $90 \%$ and $70 \%$, ranging from culture change efforts (Griffith, 2002; Mourier \& Smith, 2001; Smith, 2003), to Total Quality Management interventions (De Cock \& Hipkin, 1997; Melan, 1998; Siegal et al., 1996), Business Process Reengineering and technology change efforts (Smith, 2003; Ten Bos, 1997), mergers and acquisitions (Sorge \& Van Witteloostuijn, 2004), and downsizing and restructuring interventions (Ramaswamy \& Fernandez, 1997; Sahdev, 2004).

The cost of interventions is high. On the psychological front, periods of change are characterised by heightened emotional states and excessive anxiety (De Klerk, 2007). Changes are experienced traumatically with severe negative effects on the wellbeing, spirit, teamwork, performance, motivation and commitment levels (Abrahamson, 2004; De Klerk, 2007). Financial measures such as return on investment, return on equity and sales are negatively affected just by the announcement of layoffs (Ramaswamy \& Fernandez, 1997; Sahdev, 2004). These figures do not even include tangible costs such as large severance packages.

Notwithstanding overwhelming consistency in the failure of improvement interventions and their cost, there seems to be an irrational appeal to leaders to initiate even more interventions (Sorge \& Van Witteloostuijn, 2004). In one organisation that I am involved with, employees even developed an acronym that they express whenever a new intervention is announced: 'B-O-H-I-C-A' (bend over, here it comes again). Rational motivations for improvement interventions are not sufficient anymore; we need to gain a better understanding of the unconscious processes that drive the plethora of change interventions. The objective of this study is to provide insight into plausible drivers of the appeal for change interventions to leadership.

\section{The purpose of the study is to gain insights into our irrational attraction to interventions}

Notwithstanding the lack of efficacy of interventions to deliver on anticipated results, why do we just see so many of them? In this study, I investigate the appeal to leaders to implement change interventions, from a systems psychodynamic perspective. The purpose is to find an explanation to the lure behind interventions and to supplement existing theory, to explain recurrent change interventions better by introducing new and plausible relationships and drivers (Colquitt \& Zapata-Phelan, 2007; Tsang \& Ellsaesser, 2011). This study explores how social defences operate in ways that did not receive much attention previously. I demonstrate how improvement interventions are mobilised as defences against anxiety or as defences to maintain fantasies, which serve to reduce anxiety, and do little to help the organisation to survive in real terms.

The terms of change and improvement interventions or initiatives are used interchangeably in the discussions. They refer to any specific and intentional attempts, initiated by organisational leadership, with the intent to inflict fairly rapid and significant improvement to the status quo, and which impact a large portion of the organisation (Vinger \& Cilliers, 2006; Siegal et al, 1996).

\section{Current perspectives are too rational, we need to explore unconscious drivers}

Ample research and literature sources are available on the topic of change interventions. However, their focus appears to centre around rational explanations for the need for change interventions, the effectiveness of interventions, approaches to improve effectiveness and the effects of interventions on people and organisations. Even literature explores links between psychodynamics and change focuses mainly on the anxieties that result from change interventions, rather than the triggers of interventions. A better explanation is called for to explain the mechanisms that make leaders crave more and more improvement interventions.

Although rational motivations for the need of change interventions are abundant, there is a need for answers that go deeper into the unconscious and apparently irrational drivers of this phenomenon. As many drivers of change interventions may vary on psychodynamic phenomena, rationality can be a psychological obstacle in exploring how the influence of the unconscious on the unconscious mental forces of the mind may drive such activity (Krantz, 2010). Systems psychodynamics offers valuable perspectives to understand unconscious and apparently irrational behaviours (Gabriel \& Carr, 2002; Hirschhorn \& Gilmore, 1989).

\section{Rationale and value-add of the study}

The competitive business environment inevitably generates much anxiety - the emotional state of apprehension, characterised by unpleasant feelings of tension (Koortzen \& Cilliers, 2002). Anxiety is intensified by emotionally demanding events such as the global economic crisis (Krantz, 2010). Anxiety acts as a driving force behind many behaviours in organisations (Krantz, 2001). Excessive anxiety leads to dysfunctional defensive structures, whereas too little anxiety breeds complacency and gradual decay (Gabriel \& 
Carr, 2002; Gould, Ebers \& Clinchy, 1999; Gutmann, 1993). In order to cope with anxiety, individuals in organisations fend against the incapacitating effects of anxiety by mobilising defence mechanisms such as regression, denial, projection, rationalisation and intellectualisation (Bion, 1961; Bowins, 2004; Koortzen \& Cilliers, 2002; Miller, 1993). Defence mechanisms allow people to continue to function reasonably well in anxiety-arousing situations (Cramer, 1998, 2006; Kramer, 2010; Miceli \& Castelfranchi, 2001). Defences distort perceptions of reality in order to generate feelings that the workplace is safe, thus containing anxiety and enabling people to cope (Bain, 1998; Hoggett, 2010; Krantz, 2010; Menzies, 1960). Social defences are more than individual defence mechanisms as they explain the organised, but unconscious ways in which groups erect defensive systems to protect themselves from their unacceptable feelings that arouse from different anxieties (Krantz, 2010; Menzies, 1960).

Inevitably, anxiety plays some role in interventions which are implemented to counter business challenges. By studying the role of anxiety and its related and subsequent defence mechanisms, it is possible to explore the role of defensive structures in embarking on improvement interventions (Linklater \& Kellner, 2008).

Despite the explanatory power of the defence mechanism, which may perhaps be a defence mechanism in itself, it is a concept that has too frequently been ignored in organisational psychology (Cramer, 1998). In the systems psychodynamic perspective, the flight into structure has been explored as a defensive mechanism (e.g., Koortzen \& Cilliers, 2002). However, psychoanalytic writers have generally regarded flight into activity as a by-product of defences against anxiety, rather than a defence mechanism in itself (Corradi, 2007).

One of the paradoxes of improvement initiatives is that they can actually prevent effective change as much as enable it (Sorge \& Van Witteloostuijn, 2004). For instance, increased busyness can be an obstacle to improvement (Fusil, Gobran \& Koskimaa, 2010). Furthermore, people reach a threshold in dealing with stress, uncertainty and disorientation (Abrahamson, 2004; Marks, 2004). Less pain may yield more success in organisations that have repeatedly subjected employees to the pain and stress of initiatives (Marks, 2004). However, change without pain is unrealistic, the only way to avoid the pain is avoiding a non-essential intervention.

Susan Long wrote about perverse sins in organisations. Perverse is being defined as disposed to go counter to what ought to be done and holding on to what is wrong, even in the face of reality (Long, 2008). The obsession with change interventions, which do not deliver on expectations, appears to fit the definition of perversity. Armed with an improved theory on the drivers behind change interventions, organisations will be better prepared not to rush into unnecessary interventions and perverse activity. Avoiding non-essential interventions can free up much time, energy and effort to spend on other priorities.

\section{Research design \\ Research approach}

A complicating factor in researching defence mechanisms is that one has to rely on interpretation or inference from observation and other data, the reason being the unconscious and unintentional nature of defences. The use of defences will almost always be denied by those involved and its functioning is subject to different interpretations (Cramer, 2006). This is one of the reasons that this study was approached from the systems psychodynamic perspective. In systems psychodynamics, we treat the organisation as a complex system, beyond rationality or conscious awareness, providing insights into the way unconscious forces drive the fantasies, anxieties and defences in organisations (Bion, 1961; Koortzen \& Cilliers, 2002; Miller, 1993; Stapley, 1996).

\section{Research method}

The research design is a literature study, qualitative and explorative in character. The research design partly constitutes a phenomenological analysis of available literature in order to extract and describe probable drivers of the phenomenon of so many improvement interventions. In phenomenological analysis, the world is seen as a social construction by the actions of people, conscious and unconscious (Corley \& Gioia, 2011). Combined with the systems psychodynamic perspective, it deviates from rational realism and is ideal to study potential unconscious drivers of interventions (Hirschhorn, 1993).

The design also partly constitutes a contribution to theory building (Giorgi, 2010), not building a complete new theory, but expanding on existing theories through developing hypotheses to explore different explanations for the phenomenon being studied. As the purpose of theory is not to explain an entire phenomenon, but only aspects of it (Tsang \& Ellsaesser, 2011), this research does not attempt to provide an exhaustive explanation of drivers for interventions. Rather, through the search for linkages between theoretical concepts in order to explore new explanations (Okhuysen \& Bonardi, 2011), it aims to explain plausible ways that defensive structures contribute to the appeal of change interventions to leaders.

Industrial and organisational psychology represents an eclectic field that borrows knowledge from other foundational sciences (e.g., psychology, sociology, anthropology and philosophy) and applied sciences (e.g., organisational behaviour, economics and management) (Oswick, Fleming \& Hanlon, 2011). In developing a scientific theoretical contribution, I considered contributions from all these fields and applied different lenses to develop synergy, integration and virtual consensus (Klein, Tosi \& Cannella, 1999; Okhuysen \& Bonardi, 2011).

Data was gathered through an extensive literature search of scholarly databases. ${ }^{1}$ These databases cover more

1.Emerald Academic Source Complete, Business Source Complete, EconLit, ERIC 1.Emerald Academic Source Complete, Business Source Complete, EconLit, ERIC, Premier, MEDLINE, MLA International Bibliography, PsyARTICLES, PsycINFO, Premier, MEDLINE, MLA International Bibliography, PsyARTICLES,
Research Starters - Sociology, Soclndex and Teacher Reference Centre. 
than 9000 scholarly and peer-reviewed journals, dating back as far as 1940. By using various search words and phrases, I searched for data relevant to aspects of change improvement interventions, busyness and activity, systems psychodynamics and defence and coping mechanisms. Data analysis on the correct research methods included searches related to theory building, thematic analysis, phenomenological analysis and autoethnographic research. Articles were downloaded and data was analysed for linkages and according to its potential for a strong theoretical contribution (Corley \& Gioia, 2011). In other words, analysis focused on the richness and the degree to which data and linkages resulted in novel insights (Colquitt \& ZapataPhelan, 2007). For theory building, inductive reasoning from observations was combined with deductive reasoning from literature to end with a set of hypotheses to summarise the resulting theory (Colquitt \& Zapata-Phelan, 2007).

The systems psychodynamic perspective provided a lens through which to explore and describe unconscious and irrational drivers of interventions (Giorgi, 2008; Gould, Stapley \& Stein, 2001). Although individuals initiate interventions, systems psychodynamics posits that the individual behaves as part of the system (Gabriel, 1999). This implies that the researcher should be interested in socially and systemically relevant behaviours rather than individual case studies or anecdotes (Giorgi, 2006). The researcher asks the question 'what is usually happening', and then describes the behaviour in the context of the theoretical framework systems psychodynamics in this study.

The idea behind the data analysis was to extract cues whose existence is driven by plausibility rather than accuracy (Corley \& Gioia, 2011). The approach was not to split between 'good' initiatives and 'bad' initiatives. The idea was not to suggest that interventions are intrinsically flawed or generally unnecessary and to be avoided. I rather departed from the cognition that any intervention generates activity and consumes time, energy and other resources, notwithstanding the good intentions, outcomes or consequences. If these resources are committed to an intervention, it means that they are no available other business priorities.

The aim of any research is to provide an objective understanding of the phenomenon being investigated (Parry, 2008). When researching a phenomenon that one has been exposed to personally, research inevitably includes some autoethnographic elements as interpretations are done through the subjective lens of the researcher (Parry \& Boyle, 2009). My lens includes many years' experience as line manager and as change specialist in large organisations. I thus write from a place of tension, understanding the rational need for large-scale interventions and how to manage change, whilst being subjective about their efficacy. It is from this perspective that I opted to write in the first person, acknowledging my autoethnographic position in the research (Parry \& Boyle, 2009). Nevertheless, autoethnographic experience adds value as it allows for insightful and rich perspectives (Parry, 2008). In the analyses, I focused on objective data through withholding my own assumed reality around change interventions (Giorgi, 2008, 2010).

The interpretation of the data resulted in themes, which were abstracted into different working hypotheses that seemed to best describe the explanations suggested by the data analysis (Terre Blanche, Durrheim \& Painter, 2006). Only data that could provide insight into the research problem was included and presented in the discussions. In the discussion of the results, I first motivate how recurrent interventions can be manifestations of defence mechanisms. From this discussion, I develop a general working hypothesis, which in turn is further expanded through four detailed working hypotheses.

\section{Results}

\section{Could interventions be defence mechanisms to contain anxiety?}

Change efforts can be viewed as existing along a continuum; at one end of the continuum, efforts resemble the paranoidschizoid mode (Gould et al., 2001; Krantz, 2001). This mode is characterised by primitive defences to alleviate anxieties and compromised functioning because of idealisation, projection and a diminished capacity to grasp reality (Gould et al., 2001; Krantz, 2001; Gutmann \& Ravot-Loucheux, 2009). At the other end of the continuum are more sophisticated change efforts that resemble the depressive position. This mode is characterised by a breakdown of psychological defences and anxieties are sufficiently contained for people to think clearly, confront realities effectively and learn from experience (Krantz, 2001; Menzies, 1993). Excessive defence systems undermine reaching the depressive position by reducing too much anxiety, impeding sustainable change as organisations do not tackle the difficult issues that need to be resolved (Gutmann \& Ravot-Loucheux, 2009; Krantz, 2001).

An organisation experiencing change often cannot offer sufficient containment of anxiety, leading to more anxiety and more change (Koortzen \& Cilliers, 2002; Van Eeden, 2010). In order to cope with discomfort, the organisation needs something or someone to contain the anxiety on its behalf (Menzies, 1993), a need that is often projected onto leadership (Krantz, 2001).

\section{Are interventions not coping processes rather than defence mechanisms?}

Improvement interventions will undoubtedly be argued by some people, to represent coping mechanisms rather than defence mechanisms. Part of what makes the distinction difficult between defence and coping mechanisms, is the overlap between their two main functions: (1) to protect people from the disruptive effects of excessive anxiety arising from dangers, threats or stressors, and (2) to restore a reasonable level of functioning (Cramer, 1998, 2006; Khaleelee, 2009; Kramer, 2010; Newman, 2001).

The primary way to differentiate defences from coping mechanisms is the unconscious or conscious nature of the 
particular mechanism involved. Defences are unconscious and automatic (unintentional) processes, while coping processes are conscious and purposeful (intentional) (Cramer, 1998, 2001, 2006; Newman, 2001). It is in the misconception that an intervention is a rational and purposeful choice against a threat (Haan, 1977), that the delusional defence of flight-into-activity lies (Menzies, 1993). While interventions such as changes to structures may facilitate work, they are actually defence mechanisms to manage anxiety that leave little sustainable benefits (Krantz, 2010).

Coping and defence are not to be differentiated by outcome measures such as healthy behaviours or pathology (Cramer, 1998). For both coping and defences, it is the quantity of use that determines the relation to pathology (Cramer, 1998; Miceli \& Castelfranchi, 2001). The overuse of the same coping mechanisms across different situations, or habitual coping processes and automatic behaviours are signals of defensive behaviour rather than coping behaviours (Cramer, 1998; Kramer, 2010). The automatic and recurrent theme of new interventions is evidence of habitual behaviour and signals a shift from coping strategies to defences against anxiety.

Habitual behaviour also hints at symptoms of compulsiveness and obsessiveness, both characteristics of defence mechanisms (Cramer, 1998; Kramer, 2010). Obsessivecompulsive behaviour refers to a fixated and recurrent mental act that the person feels compelled to perform, driven by urges beyond the person's ability to control (Stapley, 2006). Obsessive-compulsive behaviour almost always manifests in dysfunctional routines (Bowins, 2004). The continual cycle of improvement intervention is an indication of obsessivecompulsive behaviour, even of perverse activity. As Long (2008, p. 15) notes, 'perversion begets perversion. Abusive cycles are hard to break.' It is in the almost obsessivecompulsive habit to rely on improvement interventions that apparent coping strategies take on the characteristics of pathological defence mechanisms.

\section{Could interventions be a defence mechanism to maintain a fantasy?}

In addition to its function to reduce anxiety, defence mechanisms can serve to maintain a fantasy (Cilliers \& May, 2010). Through cognitive distortions of reality, defence mechanisms can maintain or keep alive fantasies that are too difficult to let go of, or where the contradictory reality to the fantasy is too ghastly to acknowledge (Cramer, 1998). Distortion places a sugar coating on events and alters the perception of unfavourable events in a positive way to lessen the impact (Bowins, 2004; Gutmann \& Ravot-Loucheux, 2009). For instance, the appalling record of interventions to deliver on expected results (Smith, 2003) is suppressed or denied. The reality is that interventions are rarely productive and that a leader's ability to effect significant changes in the status quo through an intervention is minute. This is anxiety provoking and may produce emotions that are too threatening or painful to acknowledge (Bain, 1998; Hoggett, 2010; Krantz, 2010; Menzies, 1960). If organisations cannot rely on interventions and heroic leaders to rescue them from the threats, it creates a sense of helplessness (Gabriel \& Carr, 2002), what else can they rely on? Rather than facing and dealing with such reality, the fantasy is maintained that faddish interventions will rescue struggling organisations, driven by heroic leaders (Sorge \& Van Witteloostuijn, 2004). It is from this discussion that the overarching, general working hypothesis was formulated.

\section{General hypothesis: Interventions often represent social defences}

The lure of new improvement interventions to leaders appears to be a manifestation of different defence mechanisms. The unrelenting drive to initiate new interventions often does not represent coping strategies, but a defensive structure against anxiety. The act of entering into an activity might be intentional and conscious, yet the actual function it fulfils is unconscious and to release anxiety, rather than being purposeful choice. The intervention serves to resolve the anxiety from the stressor or threat, but the leap into activity is habitual and obsessive-compulsive. The true meaning behind the activity is a flight from anxiety by leadership, more so than a conscious attempt to deal with the threat. I thus formulated the following general hypothesis:

- General hypothesis: The seemingly automatic response to embark on change and improvement interventions often represent social defences, erected by leaders as they identify with projections, that serve to contain anxieties or to maintain fantasies because the prospect of losing them is too ghastly to comprehend. These defences serve to reduce anxiety to levels that are comfortable to bear, to maintain the fantasy of being in control and taking appropriate action over the challenges, or to support heroic leadership fantasies.

To provide further clarity, the general hypothesis is expanded through four detailed working hypotheses, summarised as follows:

- Hypothesis 1: Taking control over helplessness.

- Hypothesis 2: The virtue of busyness.

- Hypothesis 3: Activity is a defence against boredom and perceptible incompetence.

- Hypothesis 4: The lure of being the heroic change agent and rescuer.

These hypotheses are discussed in detail in the next section.

\section{Working hypothesis 1: Taking control over helplessness}

Initiating large-scale improvement interventions are used by leaders as defensive structures against the feelings and experiences of helplessness and powerlessness that are produced by anxiety.

Organisations can be a source of creativity and excitement especially for leaders, but they also generate anxiety. For instance, anxiety is created through the explicit demands and implicit expectations of leaders to be in control and to take the organisation to forever-higher performances, 
notwithstanding the realities in the environment (Koortzen \& Cilliers, 2002). Being in control is a strong need, and being seen to be in control is an especially strong expectancy for leaders (Corradi, 2007; Long, 2010). The experience of not being in control can produce excessive feelings of powerlessness, helplessness and an ego threat ('I cannot save the organisation!'). Taking action, such as starting an intervention is a critical ego defence to ward off anxieties associated with feelings of helplessness, powerlessness and vulnerability (Corradi, 2007). There seems to be excessive reliance by leadership on change interventions to gain control and interventions have become a metaphor for being in control (Sorge \& Van Witteloostuijn, 2004; Krantz, 2010).

A subset of this defence is engagement in frenetic, even senseless activity to enhance feelings of being in control. An instinctive defensive response to a crisis is to panic, with the need to do something, no matter what, just to feel you are doing something and to be seen to be doing something (Kotter, 2008; Rizq, 2002). When there is a challenge or a crisis, one often hears the call: 'Don't just stand there - do something!' (Linklater \& Kellner, 2008, p. 167). Too often managers mistake activity and motion as real urgency and direction (Davenport \& Prusak, 2000). On the contrary, anxiety-driven urgency manifests in frenetic, unproductive and perverse activity (Kotter, 2008), little more than unproductive defences against the anxiety.

Sometimes interventions and activity are the correct and essential ways to react to business challenges, offensive and proactive strategies to ensure sustainable success. After all, interventions have on average a statistical probability of between $10 \%$ and $30 \%$ to be successful and to deliver on the anticipated outcomes. However, activity has become a too easy tool to use for suppressing difficult emotions and as a defence mechanism against anxieties (Linklater \& Kellner, 2008; Loosemore \& Hughes, 2001).

What constitutes being out of control and helpless, or how people react to these feelings or in a crisis varies greatly for individuals (Corradi, 2007). For some, it could inhibit their capacity to take any action at all, even when it is necessary, others may perceive threats in the environment and then overreact (Khaleelee, 2009). Not being in control, combined with feelings of helplessness are particularly anxietyprovoking experiences for leaders with obsessive characteristics (Gabriel, 1999).

\section{Working hypothesis 2: The virtue of busyness}

The perceived virtue of busyness is about the fantasy that activity is worthy and admirable, whereas idleness and passivity is shameful. Leaders mobilise defence mechanisms to fend off any potential signals that may possibly leave perceptions that they are not busy enough or do not create enough busyness. The fantasy is that valuable things are accomplished by doing another initiative, even if it may create more busyness, whereas, idleness is equated to loafing or incompetence.
Chaucer candidly described the importance of looking busy many years ago in his prologue to The Canterbury Tales: 'Though there was nowhere one so busy as he, he was less busy than he seemed to be' (Chaucer, 1951, p. 28). Chaucer uses this playful line to introduce and describe the sergeant of the law. Chaucer leaves no doubt that the sergeant's busyness was a matter of show. Yet, there was something prestigious about his busyness that distinguished him from others. Clearly, busyness became a badge of honour (Gershuny, 2005). Could the same be true for leaders, that their own busyness and the busyness they install into organisations are more showmanship to earn this badge of honour, rather than real industriousness?

Greenfeld (2005) notes that in Russian, the word for busyness is the same word as used for vanity. Busyness is a variation to the vanity of materialism, instead of wanting to accumulate money, we share a fantasy that it is possible and virtuous to be forever busy (O'Connor, 2008). The proverb: 'Doing nothing is the cushion on which the devil lies', even implies that by being busy, one avoids temptation to indulge in unworthy activities. The desire to being busy and addiction to activity is ever prevalent in everyday interactions, even in the way people greet. It is quite common for people to respond to the normal greeting of 'how are you?' with a 'busy, thank you' when implying they are well. This response seems to be a veiled boasting of one's busyness, almost like Chaucer's sergeant.

With virtue tied to busyness, we tend to split between action and non-action and action (as in change and improvement interventions) became idealised as the positive, the good and desired reaction to challenges. Action and intervention became to be seen as the metaphorical good breast, whereas not taking action is the bad breast, the dry breast that cannot feed the child, and therefore the undesired route to take (Cilliers \& May, 2010). This perpetuates demand for new changes and interventions, notwithstanding the success or failure of previous interventions, for the absence of change is seen as a deficiency.

We are not only busy, but we are restless, our busyness is an expression of an inability to rest, rather than its cause (Greenfeld, 2005). Although it may appear to be irrational, busyness satisfies unconscious psychosocial needs. Maintaining the status quo is not the job of managers, change implies action and a manager is a doer (Sorge \& Van Witteloostuijn, 2004). The role of the manager is to move the organisation forward and to make impossible things happen (Kerfoot, 2007). From a psychodynamic perspective, one could hypothesise that the primary task of leadership unconsciously became to represent activity (Cilliers \& Koortzen, 2005).

\section{Working hypothesis 3: Activity is a defence against boredom and perceptible incompetence}

Initiating an improvement intervention is a flight to action and a defensive structure against boredom. It is also a defensive structure to contain anxieties about perceptible 
incompetence or not being qualified for the role as a leader. This hypothesis is related to the hypothesis around the virtue of busyness. If busyness established, came to be the badge of honour, not being busy is a signal of incompetence, which is heresy for those in leadership positions. As result, there is the need for activity to fulfil an unconscious need in leaders to be busy and to work long-hour days.

In a busy and fast-paced world, lack of activity is interpreted as dysfunction and underutilised capacity (Carroll, Parker \& Inkson, 2010). If a top manager is not busy, does not work excessive hours or keeps the organisation busy through new changes or interventions, then his or her contribution to success can be questioned (Sorge \& Van Witteloostuijn, 2004). Idleness becomes a sign of leadership incompetence, resulting in fears of being exposed as an imposter (Clance, 1985), producing intense anxieties in any senior leader. Any noticeable signs of idleness must thus be fended off at all cost.

The other extreme of excessive busyness is boredom (loss of tension and unpredictability, tired by dullness) (Carroll et al., 2010). Carroll et al. (2010) found that senior executives frequently feel bored, which they juxtapose with facing stimulating challenges. Participants in their study perceived boredom as antithetical to leadership, a disease for which the only cure is creating challenges for yourself. Alarmingly, senior managers seek and create change not only to advance the interests of their organisations, but also to quell their own restlessness and to evade boredom (Carroll et al., 2010). Bored managers may introduce unnecessary or even dysfunctional change for change's sake, moving from initiative to initiative without necessarily advancing the organisation (Carroll et al., 2010).

\section{Working hypothesis 4: The lure of being the heroic change agent and rescuer}

Being the heroic change agent and messianic rescuer who saves the organisation from failure through a courageous crusade, is a narcissistic fantasy that drives many change interventions. Embarking on interventions represents a defensive structure that seeks to maintain the fantasy of being a powerful and omnipotent leader who will determine and create a successful future for the organisation, rather than being weak, passive and powerless.

Projection plays a major role in this defence. Projection happens when a part of the system projects its own dependencies, fantasies or anxieties onto another part of the system (Cilliers, 2003; Stapley, 2006). For instance, group members project their anxieties and dependencies onto leadership to become heroic and omnipotent figures, a fantasy of a proverbial messiah who is able to rescue the organisation from any threats (Gabriel, 1999; Gould, 2010; Long, 2010). Through identifying with projected fantasies, leaders become containers of anxiety and victims to the pressure for performance (Koortzen \& Cilliers, 2002). To be a hero or maintain the fantasy of being a heroic rescuer, one needs a heroic feat - a virtual monument or conquest to be remembered by. In the organisational context, what better monument could there be than successfully launching and completing a grandiose project, which can live in the memory of the organisation as your heroic crusade that rescued the organisation from the threats it was facing?

Projection and projective identification can be on and within abstract constructs (Cilliers \& May, 2010). For instance, change interventions and activity have been depicted as the good and right remedy to rescue organisations in difficult times, whereas inactivity and non-grandiose tasks have been depicted to be the bad object and not diligent. The realistic view of what is good and bad becomes distorted or invisible. This is in line with the splitting between change and action being good and industrious, versus not taking action being regarded as bad and unproductive.

Defending the fantasy of the heroic leader manifests in different ways for different individuals. For instance, leaders with narcissistic characteristics could be especially prone to fantasies to become the heroic rescuer and messianic leader, or to identify with such projections (Gabriel, 1999; Khaleelee, 2009). Another factor is the ways competition or rivalry between leaders may arouse such defences (Koortzen \& Mauer, 2005). Managers who operate predominately from a paranoid-schizoid frame are especially grandiose in their aims, unrealistic in their expectations and ultimately ineffectual in their efforts (Krantz, 2001). One can speculate that these managers will be more inclined to initiate change interventions as defence mechanisms. Although some competition between managers is healthy, competition can spiral into attempts to outshine each other with grandiose acts of heroism. Competing leaders initiate and take on unnecessary new projects in their strive for admiration (Koortzen \& Mauer, 2005; Long, 2010).

Change interventions itself became a prestigious activity (Sorge \& Van Witteloostuijn, 2004). Managers of change interventions are seen as inspirational corporate heroes who turn things around through grandiose projects (Krantz, 2001). This perception was formed, not necessarily based on substantiated successes. Rather, it is largely manipulated by a change management industry and management best-sellers, myths that are formed about their skills, their actions and the programmes they design, even if such myths are hopelessly romantic or woefully exaggerated (Griffith, 2002).

\section{Discussion}

This study investigates the lure to leaders to implement change interventions and provides plausible drivers to explain this attraction. The results indicate that interventions are often started as defence mechanisms that serve to contain anxieties or to maintain fantasies. These defence mechanisms mutate into social defences as leadership identifies with organisational and societial projections, and erects defensive structures against subsequent anxieties or to maintain fantasies related to leadership. Although there are enticing rational motivations to embark on 
improvement interventions, leaders will do well if they defy these projections and resist the rush or urge to rescue and intervene with another intervention when the anxiety rises. Surprisingly good results can be achieved if leaders create more slack time, within which the organisation can In many ways, our perpetual busyness may reflect the experience of Sisyphus - condemned by Pluto to a perpetuity of pushing a large stone to the top of a mountain, only to see it return to its original position when released (Camus, 1955). Initiating non-essential interventions are no less absurd organisations probably spend about as much time pushing interventions as metaphorical rocks. Through confronting the absurd busyness of perpetual change interventions with little success, we may take respite from pushing our rocks on their endless journeys (Perkmann \& Spicer, 2008).

Large-scale improvement interventions can be started by leaders as defensive structures to contain feelings of anxiety, helplessness and powerlessness. Frenetic activity provides a false sense of control. Clearly, busyness became a badge of honour in the modern organisation and leaders mobilise defence mechanisms to fend off any signals that may leave perceptions that they are not busy enough or do not create enough busyness. Could the problem be that we are committed to busyness, but not to deep change, innovation and effectiveness? Kerfoot (2007) rightfully questions whether we came to worship at the altar of busyness to the point that the effectiveness and efficiency of what we do is impaired?

If busyness is the badge of honour, not being busy is a signal of incompetence, which is an intolerable idea for those in leadership positions. Initiating improvement interventions can be a defence mechanism to fend off signs of boredom and anxieties about any possible signs of incompetence or being unqualified for a senior leadership position. If leaders' response to fears of boredom is to seek challenges by propelling organisations into continuous cycles of change, organisational life will continue to be characterized by disruptive change with sweeping and superficial novelty (Carroll et al., 2010). Being a heroic change agent is a narcissistic fantasy to rescue the organisation from failure and drives many change interventions. This defensive structure seeks to maintain the fantasy of being a messianic leader, one who will forever create a successful organisation (Gould, 2010; Long, 2010).

It is paradoxical, but improvement initiatives can actually prevent effective change as much as enable it. An enemy to improvement is the availability of time - excessive busyness does not allow time to think properly or spend quality time on high priority tasks (Fusil et al., 2010). Leaders need to become aware of what their systems are projecting onto them, how they take in the projections, their valences and the resultant implications. Organisations that lack reflective space are oblivious to the implications of their busyness. The organisation may appear to be responsive, but in fact is acting in a repetitive way without thought or reflection (Bain, 1998). In the heroic crusades, energies are often diverted into dysfunctional interventions, away from capitalising on the strengths inherent in the organisation (Griffith, 2002).

With increasing business challenges, proper management of anxiety, became a central task in organisations (Koortzen \& Cilliers, 2002; Krantz, 2010). Organisations need to become more astute to mobilise coping mechanisms and to rely less on defensive structures to deal successfully with business challenges. The problem with relying too strongly on defences is that they may be effective in reducing anxiety, but the overuse of defences stifles processes critical to organisational success (Menzies, 1993; Zmud, 1999). Organisational defences immerse leaders in delusions in which they pursue fanciful projects, while disregarding real problems and opportunities of the business (Krantz, 2010; Menzies, 1960). Even though organisational changes are often ineffective or counter-productive, they are followed too habitually by yet another intervention and even more anxieties (Sorge \& Van Witteloostuijn, 2004). The organisation then finds itself at the centre of a vicious circle of continual interventions and excessive busyness (Gabriel \& Carr, 2002).

Change interventions became so central to the management paradigm that its existence is merely accepted rather than being challenged. Change management has become more than a mere discipline, it now resembles the characteristics of a fad with the ingredients of a mystique movement, driven by a whole industry of change consultants and writers (Sorge \& Van Witteloostuijn, 2004). Organisations therefore need new ways of thinking and operating to deal effectively with the demands and anxieties from the competitive business world. By understanding how defence mechanisms parade as coping mechanisms, leaders can become aware of the risk of initiating more improvement interventions. It can be concluded that if change and improvement interventions generate busyness without accompanying improvements, it is a waste of time and energy and just senseless busyness - a lively, yet meaningless activity (Greenfeld, 2005).

Change interventions are not always good and may even be prohibiting real change in organisations. Organisations may be able to achieve better results by less activity. Leaders should therefore carefully contemplate the best strategies against business challenges and be cautious against embarking on new change and improvement interventions that parade as coping strategies. We need leaders who are prepared to suspend the frenetic pace of new interventions, leaders with the courage to confront boredom with reflection rather than fantasised heroic actions (Perkmann \& Spicer, 2008). Far too frequently, acting is a substitute for thinking a refusal to reflect on why we are doing what we are doing.

We all know the fable of the emperor's new clothes - the naked emperor with the delusion of wearing an exquisite gown, until a boy called the truth. Perhaps it is time for someone to call the truth that the proverbial change emperor has no clothes - change interventions are parading themselves in front of scholars and practitioners in little more than a wig and some cheery make-up (Cordery, 2004). Do the changefatigued organisations really need all their interventions; do they really need to be as busy as they are? It does not appear 
to be so. In the organisational context, one could perhaps rephrase Chaucer's phrase to: 'Though there was nowhere one so busy as he, he was less busy than he ought to be.'

Due to the unconscious nature of defence mechanisms, their functioning is open to different interpretations and specific postulations about them are thus subject to criticism. The working hypotheses presented in this article represent a search for meaning and plausible explanations, not truth (Hansen, 2006). The working hypotheses are to be read as reasonable explanations of the phenomenon, not a prediction about what will happen in all circumstances (Boyle \& Parry, 2007). The value of the explanations and working hypotheses of this study lies in their practical meaning and plausibility, rather than in being universal truths (Parry, 2008). It challenges existing thinking beyond the obvious and the rational, articulates new insights and improves understanding of drivers of interventions in organisations by offering unique points of view. It is finally the responsibility of the individual reader to make up her or his mind about potential predictive validity.

The subjective lens of the researcher in any study with regards to observations and interpretations is one of the limitations to this study (Parry \& Boyle, 2009). Another limitation is the fact that no theory can include all the causes to explain a phenomenon, a theory only explains certain aspects of a phenomenon (Tsang \& Ellsaesser, 2011). This study does not explore or attempt to explain all the causes or drivers of continual change interventions. For instance, reasons for failure of interventions were not explored, neither how such failures could be related to the reasons for which they were initiated. It does not explore the contributions to this phenomenon by other accomplices, such as change managers, consultants and esteemed writers. The study only explores the attraction of interventions to leaders from the systems psychodynamics perspective. This does not refute, nor deny the existence of rational and conscious drivers of the phenomenon, but it does not include or cater for offering such explanations.

I opted for a provocative tone and somewhat controversial perspective in the anticipation that it will stimulate a debate and more research towards finding creative alternatives for the stubborn problems surrounding change and improvement interventions. It is hoped that the hypotheses in this study would be followed by empirical studies to analyse actual leaders and their respective change interventions and to explore the drivers that lead to those interventions. As the drivers of interventions are often unconscious - defences are by nature unconscious - it is preferable to conduct such studies also from a system psychodynamic paradigm, rather than approaching it from the rational perspective.

\section{Acknowledgements Competing interests}

The author declares that he has no financial or personal relationship(s) which may have inappropriately influenced him in writing this paper.

\section{References}

Abrahamson, E. (2004). Change without pain: How managers can overcome initiative overload, organizational chaos, and employee burnout. Boston: Harvard Business School Press.

Bain, A. (1998). Social defenses against organizational learning. Human relations, 51(3), 413-429. http://dx.doi.org/10.1023/A:1016952722628

Bion, W.R. (1961). Experiences in groups. London: Tavistock Publications. http:// dx.doi.org/10.4324/9780203359075

Bowins, B. (2004). Psychological defense mechanisms: A new perspective. American Journal of Psychoanalysis, 64(1), 1-26. http://dx.doi.org/10.1023/ B:TAJP.0000017989.72521.26, PMid:14993839

Boyle, M., \& Parry, K. (2007). Telling the whole story: The case for organizational autoethnography. Culture \& Organization journal, 13(3), 185-190.

Brunning, H., \& Perini, M. (Eds.). (2010). Psychoanalytic perspectives on a turbulant world. London: Karnac.

Buchanan, D.A., \& Bryman, A. (Eds.). (2009). The SAGE handbook of organizational research methods. London: Sage Publications Ltd.

Camus, A. (1955). The myth of Sisyphus and other essays tales. (Justin O'Brien, Trans.). New York: Vintage Books. (Original work published 1942 Gallimard)

Carroll, B.J., Parker, P., \& Inkson, K. (2010). Evasion of boredom: An unexpected spur to leadership? Human Relations, 63(7), 1031-1049. http://dx.doi. org/10.1177/0018726709349864

Chaucer, G. (1951). The Canterbury tales. (N. Coghill, Trans.). Harmondsworth, England: Penguin Books.

Cilliers, F. (2003). A systems psychodynamic perspective on burnout. SA Journal of Industrial Psychology/SA Tydskrif vir Bedryfsielkunde, 29(4), 26-33.

Cilliers, F., \& Koortzen, P. (2005). Working with conflict in teams - The CIBART model. HR Future, October, 52-62.

Cilliers, F., \& May, M. (2010). The popolarisation of positive psychology as a defence against behavioural complexity in research and organisations. SA Journal of Industrial Psychology/SA Tydskrif vir Bedryfsielkunde, 36(2), 2-11.

Clance, P.R. (1985). The imposter phenomenon: Overcoming the fear that haunts your success. Atlanta, GA: Peachtree Publishers, Ltd.

Colquitt, J.A., \& Zapata-Phelan, C.P. (2007). Trends in theory building and theory testing A five-decade study of the Academy of Management. Academy of Management Journal, 50(6), 1281-1303. http://dx.doi.org/10.5465/AMJ.2007.28165855

Cordery, J. (2004). Another case of the emperor's new clothes? Journal of Occupational and Organizational Psychology, 77(4), 481-484. http://dx.doi. org/10.1348/0963179042596432

Corley, K.G., \& Gioia, D.A. (2011). Building theory about theory building: What constitutes a theoretical contribution? Academy of Management Review, 36(1), 12-32. http://dx.doi.org/10.5465/AMR.2011.55662499

Corradi, R.B. (2007). Turning passive into active: A building block of ego and fundamental mechanism of defense. Journal of the American Academy of
Psychoanalysis \& Dynamic Psychiatry, 35(3), 393-416. http://dx.doi.org/10.1521/ Psychoanalysis \& Dynamic Psychiatry,
jaap.2007.35.3.393, PMid:17907909

Cramer, P. (1998). Coping and defense mechanisms: What's the difference? Journal of Personality, 66(6), 919-946. http://dx.doi.org/10.1111/1467-6494.00037

Cramer, P. (2001). The unconscious status of defense mechanisms. American Psychologist, 56(9), 762-763. http://dx.doi.org/10.1037/0003-066X.56.9.762 PMid:11558362

Cramer, P. (2006). Protecting the self: Defense mechanisms in action. New York: The Guilford Press.

Davenport, T.H., \& Prusak, L. (2000). Working knowledge: How organizations manage what they know. Boston: Harvard Business School Press.

De Cock, C., \& Hipkin, I. (1997). TQM and BPR: beyond the myth. Journal of Management Studies, 34(5), 659-676. http://dx.doi.org/10.1111/14676486.00067

De Klerk, J.J. (2007). Healing emotional trauma in organizations. Organization Development Journal, 25(2), 35-41.

Fusil, O., Gobran, T., \& Koskimaa, P. (2010). The Change-capable organization. The online Journal of High-performance Business, Retrieved May 09, 2011, from http://www.accenture.com/us-en/outlook/Pages/outlook-journal-2010-changecapable-organization.aspx

Gabriel, Y. (1999). Organizations in depth. London: Sage Publications.

Gabriel, Y., \& Carr, A. (2002). Organizations, management and psychoanalysis: An overview. Journal of Managerial Psychology, 17(5), 348-365. http://dx.doi. org/10.1108/02683940210432600

Gershuny, J. (2005). Busyness as the badge of honor for the new superordinate working class. Social Research, 72(2), 287-314.

Giorgi, A. (2006). Concerning variations in the application of the phenomenological method. Humanistic Psychologist, 34(4), 305-319. http://dx.doi.org/10.1207/ s15473333thp3404_2

Giorgi, A. (2008). Difficulties encountered in the application of the phenomenological method in the social sciences. Indo-Pacific Journal of Phenomenology, 8(1), 1-9.

Giorgi, A. (2010). Phenomenological psychology: A brief history and its challenges. Journal of Phenomenological Psychology, 41(2), 145-179. http://dx.doi. org/10.1163/156916210X532108 
Gould, L.J. (2010). Barack Obama's postpartisan dream: Leadership and the limits of the depressive position. In H. Brunning \& M. Perini (Eds.), Psychoanalytic perspectives on a turbulant world (pp. 159-168). London: Karnac.

Gould, L.J., Ebers, R., \& Clinchy, R.M. (1999). The systems psychodynamics of a joint venture: Anxiety, social defenses, and the management of mutual dependence. Human Relations, 52(6), 697-722. http://dx.doi. org/10.1177/001872679905200602

Gould, L., Stapley, L.F., \& Stein, M. (Eds.). (2001). The systems psychodynamics of organizations: Integrating the group relations approach, psychoanalytic, and open systems perspectives. London: Karnac.

Greenfeld, L. (2005). When the sky is the limit: Busyness in contemporary American society. Social Research, 72(2), 315-338.

Griffith, J. (2002). Why change management fails. Journal of Change Management, 2(4), 297-304. http://dx.doi.org/10.1080/714042516

Gutmann, D. (1993). Reduction in the effectiveness of social systems as a defense against anxiety. Journal of Career Development, 20(1), 85-89. http://dx.doi. org/10.1007/BF02105207

Gutman, D. (Ed.). (2009). From transformation to transformaction: Methods and practices. London: Karnac.

Gutmann, D., \& Ravot-Loucheux, P. (2009). Anxiety and passion: About the inscapability of depression. In D. Gutmann (Ed.), From transformation to transformaction: Methods and practices (pp. 243-250). London: Karnac.

Haan, N. (1977). Coping and defending. New York: Academic Press.

Hansen, H. (2006). The ethnonarrative approach. Human Relations, 59(8), 1049-1075. http://dx.doi.org/10.1177/0018726706068770

Harvey, M., Novicevic, M.M., Buckley, M.R., \& Halbesleben, J.R. (2004). The Abilene paradox after thirty years: A global perspective. Organizational Dynamics, 33(2), paradox after thirty years: A global perspective. Organization
215-226. http://dx.doi.org/10.1016/j.orgdyn.2004.01.008

Hirschorn, L. (1997). Reworking authority. Cambridge: MIT Press.

Hirschhorn, L., \& Gilmore, T.N. (1989). The psychodynamics of a cultural change: Learnings from a factory. Human Resource Management, 28(2), 211-233. http:// dx.doi.org/10.1002/hrm.3930280208

Hoggett, P. (2010). Government and the perverse social defence. British Journal of Psychotherapy, 26(2), 202-212. http://dx.doi.org/10.1111/j.1752 0118.2010.01174.x

Kerfoot, K. (2007). Beyond busyness: Creating slack in the organization. Dermatology Nursing, 19(1), 107-109.

Khaleelee, O. (2009). The use of the defense mechanism test to aid in understanding the personality of senior executives and the implications for their careers. Rorschachiana, 30(1), 73-96. http://dx.doi.org/10.1027/1192-5604.30.1.73

Klein, K.J., Tosi, H., \& Cannella, A.A. (1999). Mulitilevel theory building: Benefits, barriers, and new development. Academy of Management Review, 24(2), 243248. http://dx.doi.org/10.5465/AMR.1999.1893934

Koortzen, P., \& Cilliers, F. (2002). The psychoanalytic approach to team development In R.L. Lowman (Ed.), The California School of Organizational Studies handbook of organizational consulting psychology: Comprehensive guide to theory, skills and techniques (pp. 260-284). San Francisco: A Wiley Imprint.

Koortzen, P., \& Mauer, K.F. (2005). A theoretical interpersonal style repertoire for middle-level managers. SA Journal of Industrial Psychology/SA Tydskrif vir Bedryfsielkunde, 31(3), 39-45.

Kotter, J. (2008). Shared urgency. Leadership Excellence, 25(9), 3-4.

Kotter, J.P., \& Schlesinger, L.A. (2008). Choosing Strategies for Change. Harvard Business Review, 86(7/8), 130-139.

Kramer, U. (2010). Coping and defence mechanisms: What's the difference? Second act. Psychology and Psychotherapy: Theory, Research and Practice, 83(2), 207221.

Krantz, J. (2001). The systems psychodynamics of organizations: Integrating the group relations approach, psychoanalytic, and open systems perspectives. In L.J. Gould, L.F. Stapley \& M. Stein (Eds.), The systems psychodynamics of organizations: Integrating the group relations approach, psychoanalytic, and open systems perspectives (pp. 133-156). London: Karnac.

Krantz, J. (2010). Social defences and twenty-first century organizations. British Journal of Psychotherapy, 26(2), 192-201. http://dx.doi.org/10.1111/j.1752 0118.2010.01173.x

Linklater, J., \& Kellner, K. (2008). Don't just do something, stand there: Using action learning to help organizations work with anxiety. Action Learning: Research \& Practice, 5(2), 167-172. http://dx.doi.org/10.1080/14767330802185855

Long, S. (2008). The perverse organization and its deadly sins. London: Karnac Books.

Long, S. (2010). Images of leadership. In H. Brunning \& M. Perini (Eds.), Psychoanalytic perspectives on a turbulent world (pp. 179-200). London: Karnac.

Loosemore, M., \& Hughes, W.P. (2001). Confronting social defence mechanisms: Avoiding disorganization during crises. Journal of Contingencies \& Crisis Management, 9(2), 73-88. http://dx.doi.org/10.1111/1468-5973.00156

Lowman, R.L. (Ed.). (2002). The California School of Organizational Studies handbook of organizational consulting psychology: Comprehensive guide to theory, skills and techniques. San Francisco: A Wiley Imprint.
Marks, M.L. (2004). Review of 'Change without pain: How managers can overcome initiative overload, organizational chaos and employee burnout'. Personnel initiative overload, organization
Psychology, 57(4), 1062-1064.

Melan, E.H. (1998). Implementing TQM: A contingency approach to intervention and change. International Journal of Quality Science, 3(2), 126-146. http://dx.doi. org/10.1108/13598539810370297

Menzies, I.E. (1960). A case-study in the functioning of social systems as a defence against anxiety: A report on a study of the nursing service of a general hospital. Human Relations, 13(1), 95-121. http://dx.doi.org/10.1177/001872676001300201

Menzies, I.E. (1993). The functioning of social systems as a defence against anxiety. London: Tavistock Institute of Human Relations.

Miceli, M., \& Castelfranchi, C. (2001). Further distinctions between coping and defense mechanisms? Journal of Personality, 69(2), 287-296. http://dx.doi. org/10.1111/1467-6494.00146, PMid:11339800

Miller, E.J. (1993). From dependency to autonomy: Studies in organization and change. London: Free Association Books.

Mourier, P., \& Smith, M.E. (2001). Conquering organizational change: How to succeed where most companies fail. Atlanta: CEP Press.

Newman, L.S. (2001). Coping and defense: No clear distinction. American Psychologist, 56(9), 760-761. http://dx.doi.org/10.1037/0003-066X.56.9.760, PMid:11558360

O'Connor, M. (2008). Musings on busyness. Minnesota Medicine, 91(12), 28-31.

Okhuysen, G., \& Bonardi, J. (2011). Editors' comments: The challenges of building theory by combining lenses. Academy of Management Review, 36(1), 6-11. http://dx.doi.org/10.5465/AMR.2011.55662498

Oswick, C., Fleming, P., \& Hanlon, G. (2011). From borrowing to blending: Rethinking the process of organizational theory building. Academy of Management Review, 36(2), 318-337. http://dx.doi.org/10.5465/AMR.2011.59330932

Parry, K.W. (2008). Viewing the leadership narrative through alternate lenses: An autoethnographic investigation. Management Review, 19(1/2), 126-147.

Parry, K., \& Boyle, M. (2009). Organizational autoethnography. In D.A. Buchanan \& A. Bryman (Eds.), The SAGE handbook of organizational research methods (pp. 690-702). London: Sage Publications Ltd.

Perkmann, M., \& Spicer, A.T. (2008). How are management fashions institutionalized? The role of institutional work. Human Relations, 61(6), 811-844. http://dx.doi. org/10.1177/0018726708092406

Ramaswamy, V.M., \& Fernandez, R. (1997). The effectiveness of corporate restructuring: An analysis. Academy of Accounting and Financial Studies Journal, $1(2), 52-71$.

Rizq, R. (2002). Is there anybody there? A psychodynamic view of panic attack. British Journal of Guidance \& Counselling, 30(1), 81-92. http://dx.doi. org/10.1080/030698880220106537

Sahdev, K. (2004). Revisiting the survivor syndrome: The role of leadership in implementing downsizing. European Journal of Work \& Organizationa Psychology, 13, 165-196. http://dx.doi.org/10.1080/13594320444000056

Siegal, W., Church, A.H., Javitch, M., Waclawski, J., Burd, S., Bazigos, M. et al (1996). Understanding the management of change: An overview of managers' perspectives and assumptions in the 1990s. Journal of Organizational Change Management, 9(6), 54-80. http://dx.doi.org/10.1108/09534819610150521

Smith, M.E. (2003). Changing an organization's culture: Correlates of success and failure. Leadership \& Organization Development Journal, 24(5/6), 249-262. http://dx.doi.org/10.1108/01437730310485752

Sorge, A., \& Van Witteloostuijn, A. (2004). The (non)sense of organizational change: An essay about universal management hypes, sick consultancy metaphors, and healthy organization theories. Organzation Studies, 25(7), 1205-1231. http:// dx.doi.org/10.1177/0170840604046360

Stapley, L.F. (1996). The personality of the organization: A psycho-dynamic explanation of culture and change. London: Free Association Books.

Stapley, L.F. (2006). Individuals, groups, and organizations beneath the surface: An introduction. London: Karnac Books.

Ten Bos, R. (1997). Business process redesign: The wheel of Ixion. Employee Relations, 19(3), 248-262. http://dx.doi.org/10.1108/01425459710176972

Terre Blanche, M., Durrheim, K., \& Painter, D. (2006). Research in practice. Applied methods for the social sciences. Cape Town: UCT Press.

Tsang, E.W., \& Ellsaesser, F. (2011). How contrastive explanation facilitates theory building. Academy of Management Review, 36(2), 404-419. http://dx.doi. org/10.5465/AMR.2011.59330963

Van Eeden, R. (2010). Exploring the development of an organisational culture of control and dependency from a systems psychodynamic perspective. SA Journal of Industrial Psychology/SA Tydskrif vir Bedryfsielkunde, 36(1), 1-11. http:// of Industrial Psychology/SA Tydsk
dx.doi.org/10.4102/sajip.v36i1.854

Vinger, G., \& Cilliers, F. (2006). Effective transformational leadership behaviours for managing change. SA Journal of Human Resource Management/SA Tydskrif vir Menslikehulpbronbestuur, 4(2), 1-9.

Welsh, A. (2005). Business is busyness, or the work ethic. Social Research, 72(2), $471-500$.

Zmud, R. (1999). Learning dysfunctions in information systems development: Overcoming the social defences with transitional objects. MIS Quarterly, 23(4), Ixvii-Ixvii. 